\title{
Evapotranspiration and crop coefficients of Moringa oleifera under semi-arid conditions in Pernambuco
}

\author{
Célia S. dos Santos ${ }^{1}$, Abelardo A. de A. Montenegro ${ }^{1}$, Márcio A. L. dos Santos ${ }^{2}$ \& Elvira M. R. Pedrosa ${ }^{1}$ \\ ${ }^{1}$ Universidade Federal Rural de Pernambuco/Departamento de Engenharia Agrícola. Recife, PE. E-mail: celia@agro.eng.br (Corresponding author); \\ abelardomontenegro666@yahoo.com.br; elvira.pedrosa@ufrpe.br \\ ${ }^{2}$ Universidade Federal de Alagoas/Campus Arapiraca/Departamento de Agronomia. Arapiraca, AL. E-mail: mal.santo@hotmail.com
}

\section{Key words:}

irrigation management water requirement perennial oilseed crop

\section{A B S T R A C T}

Efficient water use in agriculture is fundamental, especially in semi-arid regions where water scarcity is intense. The aim of this study was to estimate water requirements and crop coefficients in the different phenological stages of Moringa oleifera. The experiment was carried out from February to April 2015 at the Experimental Unit for Reuse and Hydrological Management, located in Mutuca, PE (7' 15’ 18” S, 35 52" 40" W, 550 m). A lysimeter was used to estimate crop evapotranspiration. Reference evapotranspiration (ETo) was estimated by indirect methods. In the lysimeter, soil salinity and leaf water potential of the crop were monitored. The direct and indirect methods presented an excellent performance compared with the standard grass-lysimeter, especially Hargreaves-Samani, which presented a remarkable result for the study area. Crop coefficients $(\mathrm{Kc})$ ranged from 0.73 to 1.73 in the different phenological stages. Moringa crop evapotranspiration (ETc) exhibited temporal variations, with a cumulative rate of $139.8 \mathrm{~mm}$, for a cumulative reference evapotranspiration of $130.97 \mathrm{~mm}$. Moringa plants showed slight water restriction, at the times of lower solar radiation.

\section{Palavras-chave: \\ manejo de irrigação necessidade hídrica oleaginosa perene}

\section{Evapotranspiração e coeficientes de cultivo da Moringa oleifera no semiárido Pernambucano}

\begin{abstract}
R E S U M O
O uso eficiente da água para agricultura é fundamental, principalmente em regiões semiáridas, onde a escassez hídrica é intensa. Objetivou-se avaliar modelos de evapotranspiração e os coeficientes de cultivo nas diferentes fases fenológicas da Moringa oleifera. O experimento foi desenvolvido na Unidade Experimental de Reúso e Manejo Hidroagrícola, localizada em Mutuca, PE, nas coordenadas geográficas: (7 15’ 18” S; 35 52’ 40” W; $550 \mathrm{~m}$ ) durante fevereiro a abril de 2015. Para estimar a evapotranspiração da cultura foi utilizado lisímetro. A evapotranspiração de referência (ETo) foi determinada por lisimetria e comparada com os métodos indiretos. No lisímetro foi realizado monitoramento da salinidade do solo e do potencial hídrico foliar da cultura. Os métodos diretos e indiretos apresentaram ótimo índice de desempenho quando comparados com o lisímetro padrão-grama, em particular Hargreaves-Samani que apresentou um ótimo resultado para área de estudo. Os coeficientes da cultura $(\mathrm{Kc})$ variaram de 0,73 a 1,73 nas diferentes fases fenológicas. A evapotranspiração da cultura (ETc) da moringa apresentou variações temporais, com taxa acumulada de 139,8 mm, para uma evapotranspiração de referência acumulada de 130,97 mm. As plantas de moringa apresentaram restrição hídrica leve, nos horários de menor radiação solar.
\end{abstract}




\section{INTRODUCTION}

Moringa (Moringa oleifera Lam.) is a species native to India with good adaptation to the edaphoclimatic conditions of the semi-arid region of Northeast Brazil (Oliveira et al., 2013). This oilseed crop can be exploited under irrigated and rainfed conditions and has great potential due to the multiplicity of uses (Lorenzi \& Matos, 2002). For being a species not commercially exploited, moringa is still little studied, especially regarding water consumption and its ecophysiological behavior.

Research on evapotranspiration and irrigation management is very important in the planning, managing and use of water resources. Agricultural activities consume large volumes of water; thus, efforts with respect to rational and efficient use of this natural resource have been made, through technologies that allow precise measurements of evapotranspiration, such as lysimeters, or through climatological data, which contribute to a good estimate of water demand and adequate irrigation management (Lacerda \& Turco, 2015).

The selection of the most adequate method to estimate reference evapotranspiration (ETo) depends on the availability of climatological data, accuracy level required and the objective (Tagliaferre et al., 2010). Many studies comparing the different ETo determination methods are found in the literature for different regions (Santos et al., 2008; Silva et al., 2014; Tanaka et al., 2016).

Likewise, many studies report the application of lysimetric devices to assess water demand and crop coefficients (Kc), such as Santos et al. (2009), Lopes et al. (2011), Odhiambo \& Irmak (2012) and Santos et al. (2016), for pepper-rosmarin (Lippia sidoides Cham.), carrot (Daucus Carota L.), soybean (Glycinemax L.) and Tabasco pepper (Capsicum frutescens L.), respectively.

Moringa Kc is still not known and needs to be studied in order to provide reliable parameters for the practice of irrigation. Thus, this study aimed to evaluate the performance of evapotranspiration estimation models and the $\mathrm{Kc}$ in the different phenological stages of Moringa oleifera, under semiarid conditions, using low-quality, moderately saline water.

\section{Material ANd Methods}

The experiment was carried out under field conditions in Mutuca, District of Pesqueira, PE, at the Pilot Experimental Unit of Sewage Treatment and Hydro-Agricultural Reuse ( $7^{\circ}$ 15’ 18” S; 35 52' 40” W; 550 m), from February to April 2015.

The climate of the region is classified as BSh, hot semiarid, according to Köppen's classification, and its mean annual rainfall is $670 \mathrm{~mm}$ (Molinier et al., 1994).

The soil is classified as hypereutrophic sodic salic Haplic Planosol (Miranda, 2010), with predominantly sandy loam texture (EMBRAPA, 2006) (Table 1).
In the experimental area, perennial oilseed crops are planted, moringa and 'chichá' (Sterculia chicha St. Hil. ex Turpin), with a total of 36 plants at spacing of $3 \times 3 \mathrm{~m}$, regularly irrigated with wastewater from pre-treated domestic sewage, which have been monitored since 2012 .

For ETc and Kc determination, a circular drainage lysimeter made of PVC was installed in the area, with a 1.45$\mathrm{m}^{2}$ evapotranspiration surface and depth for root growth of $0.7 \mathrm{~m}$. Additionally, a standard lysimeter cultivated with grass (grass-lysimeter) was used as reference surface for ETo quantification.

The crop used in the experiment was $M$. oleifera. Its seedlings were produced in polyethylene plastic bags, filled with substrate composed of inert material free from pathogens. Moringa plants were transplanted 90 days after sowing on September 29, 2014, and the experiment was conducted until 240 days after sowing (DAS).

Irrigation management in the drainage lysimeter was determined based on water balance, drainage and reference evapotranspiration obtained in the grass-lysimeter.

To monitor the evolution of electrical conductivity (EC) in the soil solution, extractors were installed at two depths, 20 and $40 \mathrm{~cm}$. The mean EC values of irrigation water and leachate were equal to 3.11 and $3.46 \mathrm{dS} \mathrm{m}^{-1}$, respectively. The mean values of total irrigation and drainage corresponded to 30.65 and $13.77 \mathrm{~mm} \mathrm{~d}^{-1}$ during the entire experimental period.

Reference evapotranspiration was calculated through the indirect methods of Penman-Monteith (Allen et al., 1998), Hargreaves-Samani (1985) and Class A pan, and through the direct method, using the standard grass-lysimeter.

Agroclimatological data to determine evapotranspiration through the different estimation methods were obtained from automatic station (HOBO-RX3000), which has data logger (RX3000), barometric pressure sensor (S-BPB-CM50), temperature and relative humidity sensor (S-THB-M008), rainfall sensor (S-RGB-M002), global solar radiation sensor (S-LIB-M002), wind speed sensor (S-WSA-M003) and wind direction sensor (S-WDA-M003).

The present study adopted a mean Class A pan coefficient of 0.75 , in agreement with studies conducted in a nearby experimental area alluvial, also in the municipality of Pesqueira, by Santiago et al. (2004). The pertinence of this value was later verified in the present study, comparing the estimates by different methods.

The performance of the indirect methods compared with the standard grass-lysimeter was evaluated through simple linear regression, Pearson correlation (r), agreement index (d) proposed by Willmott et al. (1985), and performance index (c) proposed by Camargo \& Sentelhas (1997).

ETc in the drainage lysimeter was obtained through direct measurements of the percolated volumes. Daily Kc values were

Table 1. Physical characteristics of the soil at the Experimental Unit of Sewage Treatment and Hydro-Agricultural Reuse in the layers of $0-20$ and $20-40 \mathrm{~cm}$

\begin{tabular}{|c|c|c|c|c|c|c|c|c|}
\hline \multirow{2}{*}{ Layer (cm) } & Sand & Clay & Silt & \multirow{2}{*}{$\begin{array}{c}\text { Ds } \\
\mathrm{kg} \mathrm{dm}^{-3}\end{array}$} & FC & PWP & \multirow{2}{*}{$\begin{array}{c}\text { EC } \\
\text { dS } \text { m }^{-1}\end{array}$} & \multirow{2}{*}{ Textural class } \\
\hline & & $\mathrm{g} \mathrm{kg}^{-1}$ & & & \multicolumn{2}{|c|}{$\mathrm{cm}^{-3} \mathrm{~cm}^{-3}$} & & \\
\hline $0-20$ & 855.9 & 107.7 & 36.4 & 1.42 & 0.30 & 0.20 & 0.24 & Sandy loam \\
\hline $20-40$ & 842.5 & 127.7 & 29.8 & 1.51 & 0.33 & 0.20 & 0.14 & Sandy loam \\
\hline
\end{tabular}

Ds - Soil density; FC - Field capacity; PWP - Permanent wilting point; EC - Electrical conductivity 
determined through the ratio between ETc and ETo, the latter of which was calculated by the previously mentioned direct and indirect methods.

Leaf water potential was measured at 282, 283 and 284 DAS. Readings were taken at five times: 4, 6, 8, 10, and $12 \mathrm{~h}$ of the evaluated days. A healthy leaf was collected from the middle third of the plant and the reading was immediately taken, favoring the reduction of losses through transpiration.

Plant water potential $\left(\Psi_{\mathrm{w}}\right)$ was directly measured using the Scholander pressure chamber (Model 1515D Pressure Chamber Instrument - PMS Instrument Company). Water potential data were subjected to analysis of variance by $\mathrm{F}$ test. Polynomial regression analysis (linear and quadratic) was performed using the Software SISVAR (Ferreira, 2009).

\section{Results AND Discussion}

Rainfall was the variable with highest deviation in relation to the average, unlike wind speed, which showed the lowest deviation and was classified as light breeze (Table 2).

The Hargreaves-Samani method was closer to the line (1:1), compared with the other models (Figure 1), showing higher coefficient of determination $\left(\mathrm{R}^{2}\right)$, equal to 0.9978 .

Regarding the indices " $\mathrm{d}$ " and "c", which evaluated agreement and performance, respectively, of the ETo values estimated by the proposed methods (Figure 1), all methods evaluated and compared with the standard (standard grasslysimeter) showed values of 0.99 , considered as of good agreement and classified as "excellent" for the performance criterion, for estimates of two days.

Santos et al. (2008), evaluating the performance of low-cost hydraulic weighing lysimeter in the same region, also tested the performance of some ETo estimation methods and found a very good performance for the methods of Penman-Monteith and Class A pan, compared with the lysimeter.

Similar results have been found by Borges \& Mediondo (2007), Cavalcanti Júnior et al. (2010) and Moura et al. (2013) for the Hargreaves-Samani method, in studies conducted in Jacupiranga-SP, Mossoró-RN and Vitória de Santo Antão-PE, respectively in the Tropical Zone, Semi-arid Region and 'Zona da Mata. These authors obtained "very good", "excellent" and "excellent" performance, with $\mathrm{R}^{2}$ values equal to $0.99,0.87$ and 0.93 , corroborating the present study.

On the other hand, Silva et al. (2014) found low performance of the Hargreaves-Samani method in the Fernando de Noronha Archipelago, due to the high values of wind speed in the area, which is not considered in the formulation of HargreavesSamani.

Table 2. Statistical analysis of the climatological variables used in the estimation of evapotranspiration

\begin{tabular}{lccccc}
\hline & $\begin{array}{c}\mathbf{P} \\
(\mathbf{m m})\end{array}$ & $\begin{array}{c}\text { WS } \\
\left(\mathbf{m s}^{-1}\right)\end{array}$ & $\begin{array}{c}\mathbf{T} \\
\left.\mathbf{(}^{\circ} \mathbf{C}\right)\end{array}$ & $\begin{array}{c}\text { RH } \\
(\mathbf{( \% )}\end{array}$ & $\begin{array}{c}\text { Rs } \\
\left(\mathbf{M J ~ m}^{-2} \text { day }^{-1}\right)\end{array}$ \\
Mean & 10.01 & 1.15 & 31.71 & 72.3 & 21.44 \\
Maximum & 120.00 & 1.98 & 34.02 & 85.04 & 26.94 \\
Minimum & 0 & 0.47 & 27.09 & 66.03 & 11.70 \\
Standard deviation & 26.69 & 0.36 & 1.20 & 4.93 & 3.52 \\
Coef. of variation & 2.67 & 0.31 & 0.04 & 0.07 & 0.16 \\
\hline
\end{tabular}

P-Rainfall; WS - Wind speed; T - Temperature; $\mathrm{RH}$ - Relative humidity; Rs - Solar radiation

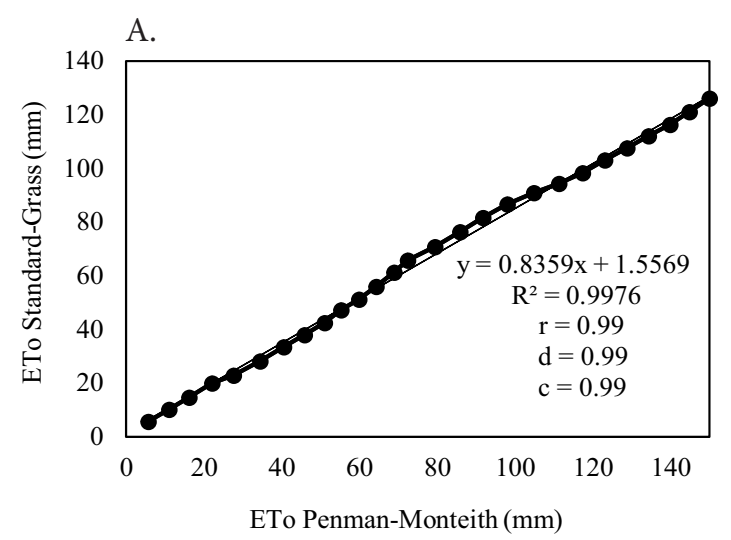

B.

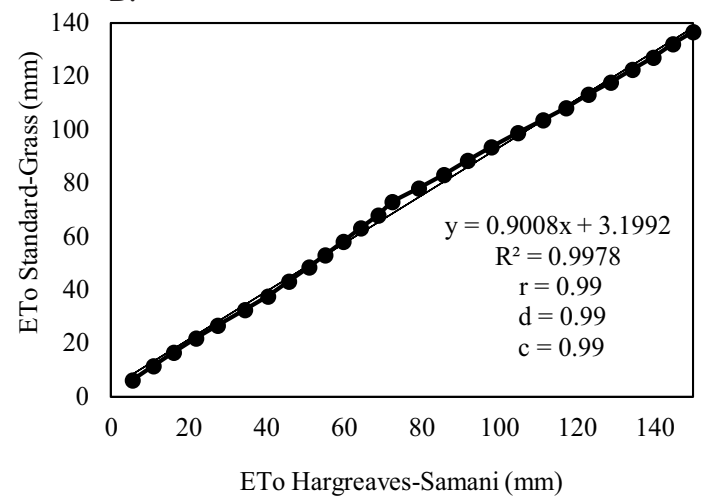

C.

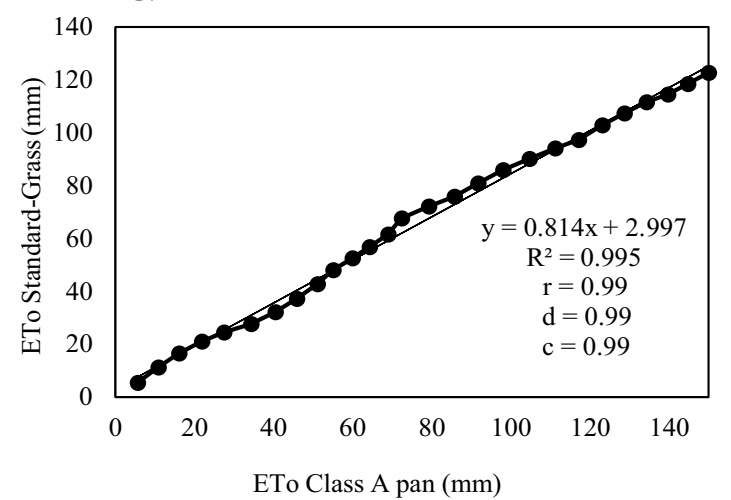

Figure 1. Correlation analysis of cumulative daily ETo measured by the standard grass-lysimeter and by the methods of Penman-Monteith (FAO-56) (A), HargreavesSamani (B) and Class A pan (C)

The correlations obtained between ETc and ETo StandardGrass in the lysimeters (Figure 2A) were high, with coefficients of determination $\left(\mathrm{R}^{2}\right)$ of 0.9957 ( $1^{\text {st }}$ stage $), 0.9936\left(2^{\text {nd }}\right.$ stage $)$, 0.9998 ( $3^{\text {rd }}$ stage), indicating high reliability of the data obtained in the lysimeters.

According to Figure 2B, until the first 253 DAS, ETc remained lower than ETo, because the leaf area of the crop was still very small, leading to evaporation and transpiration rates that, combined, resulted in lower ETc values, compared with ETo.

Moringa Kc values estimated by the different methods varied according to the daily consumption of the crop, with means of $0.75,1.75$ and 1.73 by Penman-Monteith; $0.79,1.65$ and 1.62 by Hargreaves-Samani; $0.73,1.63$ and 1.61 by the standard grass-lysimeter and $0.95,1.65$ and 1.62 by the Class A pan, respectively (Figure 2C).

It should be highlighted that, from 263 DAS to 284 DAS, on average, there is a relative stabilization in the Kc value 
A.

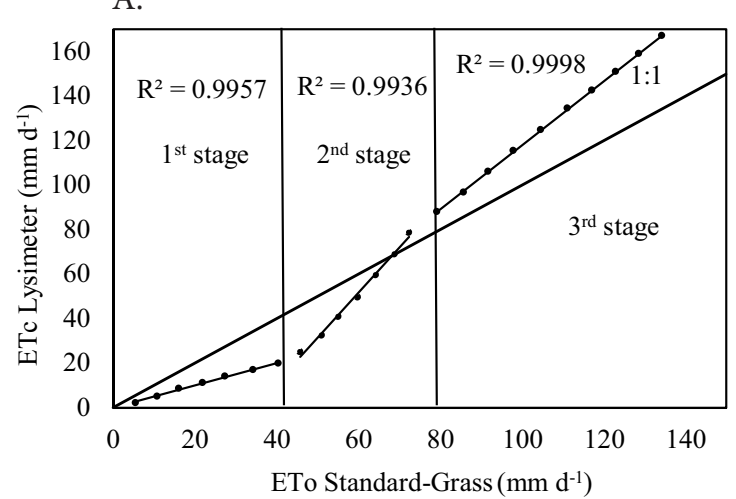

B.

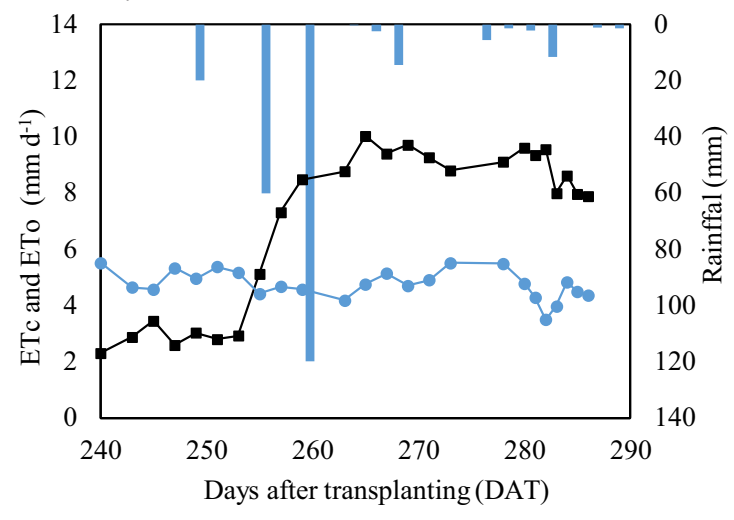

C.

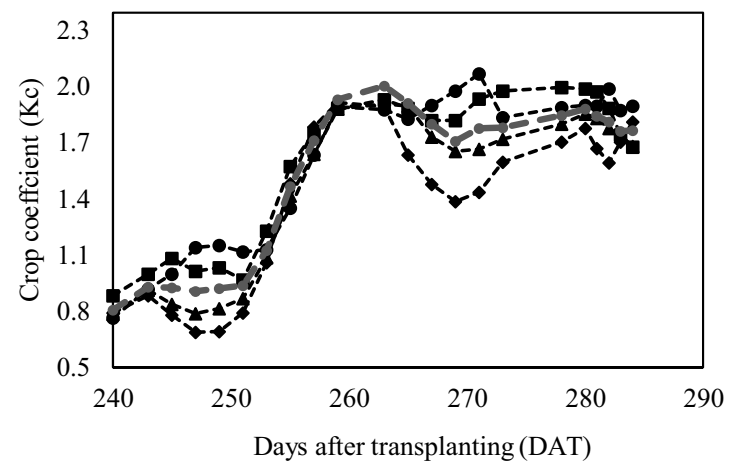

----- ETo Lis. Standard-Grass --- --- ETo Penman-Monteith

---- ETo Hargreaves-Samani ---.- ETo Class A pan

$\rightarrow-$ Average

Figure 2. Correlation analysis of ETC and ETo in lysimeter (A), variation of the ETC and ETo temporal series (B), and crop coefficient $(\mathrm{Kc})(\mathrm{C})$

(Figure 2C), indicating that the experimental period was adequate and sufficient to allow full crop growth and monitor the daily consumption of moringa during its main phenological stages. As it is a perennial crop, we opted for not repeating the evaluation over time, because it would lead to eradication of the crop.

From 253 DAS on, there was a gradual increase in ETc values because of the development of the plant, which was virtually in the middle of the flowering stage, beginning its fruiting (253 to 284 DAS). ETc in the pre-flowering stage up to fruiting showed monthly variation from 29.3 to $46.1 \mathrm{~mm}$, totaling $139.8 \mathrm{~mm}$ during the entire studied period.

Comparing the Kc values of moringa by the standard-grass method, there was an overestimation of the values estimated by the methods of Hargreaves-Samani, Penman-Monteith (FAO-
56) and Class A pan. Similarly, Colleti et al. (2012) estimated jatropha Kc under the edaphoclimatic conditions of Tangará da Serra-MT, also using drainage lysimeter, and found high Kc values, superior to those observed in the present study.

The mean value of saturation extract in the drainage lysimeter, classified as of moderate risk. At $40 \mathrm{~cm}$, which corresponds to the effective root zone, the mean value was equal to $1.13 \mathrm{dS} \mathrm{m} \mathrm{m}^{-1}$, classified as with no restriction to crop growth (Ayers \& Westcot, 1999).

Montenegro et al. (2003), working with saline groundwater in halophytes in the Northeastern semi-arid region, noted that

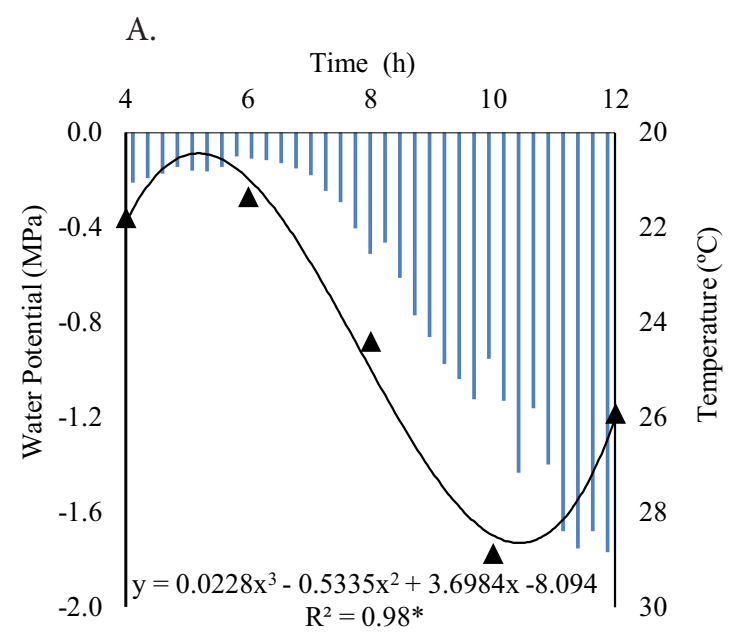

B.
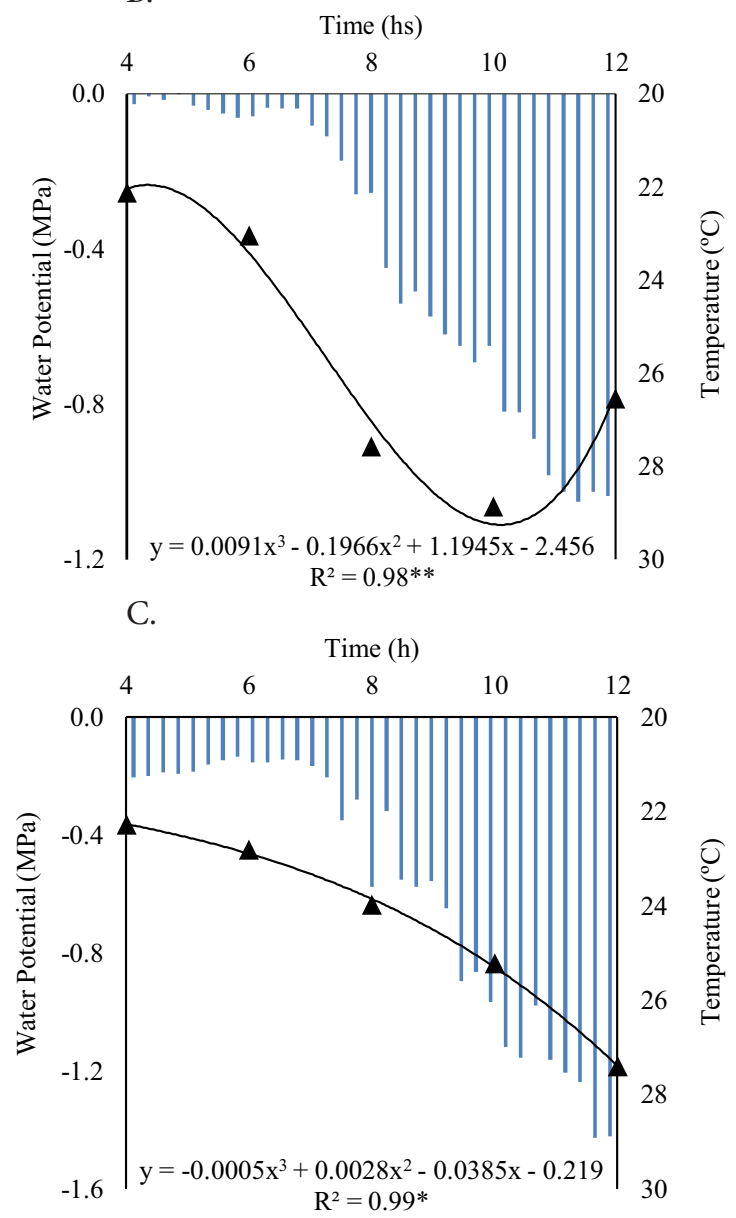

Figure 3. Relationship of mean leaf water potential at different times, at 282 (A) 283 (B), 284 (C) DAS, in Moringa oleifera cultivated in drainage lysimeter 
Atriplex numularia L. exhibited adequate development, with maximum crop coefficient of 1.03 , corroborating the crop coefficients of tree species like moringa.

Cubic polynomial models showed the best fit to leaf water potential for all days evaluated ( $p>0.05),(p>0.01),(p>0.05)$, corresponding to 282, 283 and 284 DAS (Figures $3 \mathrm{~A}, \mathrm{~B}$ and C), decreasing to $-1.18 \mathrm{MPa}$ (Figure $3 \mathrm{~A}$ ), $-0.78 \mathrm{MPa}$ (Figure $3 \mathrm{~B}$ ) and $-1.18 \mathrm{MPa}$ (Figure 3C), from the dawn to 12 a.m.

For Carbonneau (1998), leaf water potentials between 0 and $-0.2 \mathrm{MPa}$ are associated with absent to slight water restriction; between -0.2 and $-0.4 \mathrm{MPa}$, with slight to intermediate water restriction; between 0.4 and $-0.6 \mathrm{MPa}$, with intermediate to strong water restriction; and above $-0.6 \mathrm{MPa}$, with strong water restriction.

Thus, it can be inferred that, at 282, 283 and 284 DAS, $M$. oleifera plants were subjected to a slight water restriction up to 6 a.m., with mean water potential of $-0.35 \mathrm{MPa}$ for the three days. From 8 to 12 a.m., plants were subjected to a strong water restriction, showing mean value of $-1.03 \mathrm{MPa}$.

As expected, at noon, the time of highest evaporation demand, the plants showed lower values of $\Psi_{\mathrm{w}}$, compared with the evaluations at 4 and 6 a.m., representing the effect of temperature and solar radiation on the water potential of M. oleifera.

Many studies have found reduction of leaf water potential in forest species in response to water stress, such as Arcoverde et al. (2011) with Jatropha curcas L. and Rivas et al. (2013) with $M$. oleifera.

In this experiment using lysimeter, the mean values of plant height and diameter were respectively $3.38 \mathrm{~m}$ and $71.6 \mathrm{~mm}$ at 309 DAS, similar to those found by Pereira et al. (2016), which confirms that the development of the crop was representative and adequate.

\section{Conclusions}

1. All indirect methods showed excellent performance in evapotranspiration estimation, compared with the standard grass-lysimeter, particularly Hargreaves-Samani, which showed an excellent result for the studied area.

2. Crop coefficients $(\mathrm{Kc})$ varied from 0.73 to 1.73 in the different phenological stages, and stabilized at this last value.

3. Moringa crop evapotranspiration (ETc) showed temporal variations due to alterations in the atmospheric demands, with cumulative rate of $139.8 \mathrm{~mm}$, for a cumulative reference evapotranspiration of $130.97 \mathrm{~mm}$.

4. Moringa oleifera plants did not show relevant water restriction, at the times of lower solar radiation.

\section{ACKNowledgements}

To the Pernambuco State Research Foundation (FACEPE), for the scholarship Grant, and the APQ 0913-5.03/15 project Grant. To the Brazilian National Council for Scientific and Technological Development (CNPq), and to the Research Network of Reuse of Domestic Sewage Water Treatment in the Brazilian Northeast (Rereune), Grant 403519-2-13/6, for the financial support to this research. The authors thank the Postgraduate Program in Agricultural Engineering of the UFRPE.

\section{Literature Cited}

Allen, R. G.; Pereira, L. S.; Raes, D.; Smith, M. Crop evapotranspiration: Guidelines for computing crop water requirements. Rome: FAO 1998. 300p. Irrigation and Drainage Paper, 56

Arcoverde, G. B.; Rodrigues, B. M.; Pompelli, M. F.; Santos, M. G. Water relations and some aspects of leaf metabolism of Jatropha curcas young plants under two water deficit levels and recovery. Brazilian Journal of Plant Physiology, v.23, p.123-130, 2011. https://doi.org/10.1590/S1677-04202011000200004

Ayers, R. S.; Westcot, D. W. A qualidade da água na agricultura. 2.ed. Campina Grande: UFPB, 1999. 153p.

Borges, A. C.; Mediondo, E. M. Comparação entre equações empíricas para estimativa da evapotranspiração de referência na Bacia do Rio Jacupiranga. Revista Brasileira de Engenharia Agrícola e Ambiental, v.11, p.293-300, 2007. https://doi.org/10.1590/S141543662007000300008

Camargo, A. P.; Sentelhas, P. C. Avaliação do desempenho de diferentes métodos de estimativa da evapotranspiração potencial no estado de São Paulo, Brasil. Revista Brasileira de Agrometeorologia, v.5, p.89-97, 1997.

Carbonneau, A. Aspects qualitative. 1.ed. Uruguay, 1998. 276p.

Cavalcanti Júnior, E. G.; Almeida, B. M. de.; Oliveira, A. D. de.; Espínola Sobrinho, J.; Araújo, E. M. de.; Vieira, R. Y. M. Estimativa da evapotranspiração de referência para a cidade de Mossoró- RN. Revista Brasileira de Agricultura Irrigada, v.4, p.87-92, 2010. https://doi.org/10.7127/rbai.v4n200110

Coletti, A. J.; Dallacort, R.; Dalchiavon, F. C.; Martins, J. A.; Santi, A.; Inoue, M. H. Evapotranspiração e coeficiente de cultivo da cultura do pinhão manso. Revista Agrarian, v.5, p.373-383, 2012.

EMBRAPA - Empresa Brasileira de Pesquisa Agropecuária. Sistema brasileiro de classificação de solos. 2.ed. Rio de Janeiro: EMBRAPA, 2006, 306 p.

Ferreira, D. F. Estatística básica. 2.ed. Lavras: UFLA, 2009. 664p.

Hargreaves, G. H.; Samani, Z. A. Reference crop evapotranspiration from temperature. Applied Engineering Agriculture, v.1, p.96-99, 1985. https://doi.org/10.13031/2013.26773

Lacerda, Z. C. de; Turco, J. E. P. Estimation methods of reference evapotranspiration (ETo) for Uberlândia - MG. Engenharia Agrícola, v.35, p.27-38, 2015.

Lopes, O. D.; Kobayashi, M. K.; Oliveira, F. G.; Alvarenga, I. C. A.; Martins, E. R.; Corsato, C. E. Determinação do coeficiente de cultura $(\mathrm{Kc})$ e eficiência do uso de água do alecrimpimenta irrigado. Revista Brasileira de Engenharia Agrícola e Ambiental, v.15, p.548-553, 2011. https://doi.org/10.1590/S141543662011000600002

Lorenzi, H.; Matos, F. J. A. Plantas medicinais no Brasil: Nativas e exóticas cultivadas. 2.ed. Nova Odessa: Instituto Plantarum, 2002. 347p.

Miranda, R. J. A. Lâminas de irrigação com água residuária e adubação orgânica na cultura do algodão BRS safira. Campina Grande: UFCG, 2010. 84p. Tese Doutorado

Montenegro, A. A. de A.; Montenegro, S. M. G. L.; Marinho, I.; Silva, V. de P.; Andrade, A.; Silva, J. G. da. Uso de água subterrânea salina em halófitas no semi-árido nordestino. Revista Brasileira de Recursos Hídricos, v.8, p.75-84, 2003. http://dx.doi.org/10.21168/ rbrh.v8n2.p75-84 
Moura, A. R. C.; Montenegro, S. M. G. L.; Antonino, A. C. D.; Azevedo, J. R. G. de.; Silva, B. B. da.; Oliveira, L. M. M. de. Evapotranspiração de referência baseada em métodos empíricos em bacia experimental no estado de Pernambuco - Brasil. Revista Brasileira de Meteorologia, v.28, p.181-191, 2013. https://doi. org/10.1590/S0102-77862013000200007

Molinier, M.; Albuquerque, C. H. C. de; Cardier, E. Análise de pluviometria e isoietas homogeneizadas do Nordeste brasileiro. Recife: SUDENE, 1994. 58p.

Odhiambo, L. O.; Irmak, S. Evaluation of the impact of surface residue cover on single and dual crop coefficient for estimating soybean actual evapotranspiration. Agricultural Water Management, v.104, p.221-234, 2012. https://doi.org/10.1016/j.agwat.2011.12.021

Oliveira, F. de A. de; Oliveira, M. K. T. de; Silva, R. C. P. da; Silva, O. M. dos P. da; Maia, P. de M. E.; Cândido, W. dos S. Crescimento de mudas de moringa em função da salinidade da água e da posição das sementes nos frutos. Revista Árvore, v.37, p.79-87, 2013. https://doi.org/10.1590/S0100-67622013000100009

Pereira, K. T. O.; Oliveira, F. de A.; Cavalcante, A. L. G.; Dantas, R. de P.; Oliveira, M. K. T. de.; Costa, J. P. B. de M. Qualidade de mudas de moringa sob diferentes níveis de nutrientes aplicados via fertirrigação. Pesquisa Florestal Brasileira, v.36, p.497-504, 2016. https://doi.org/10.4336/2016.pfb.36.88.1038

Rivas, R.; Oliveira, M. T.; Santos, M. G. Three cycles of water deficit from seed to young plants of Moringa oleifera woody species improves stress tolerance. Plant Physiology and Biochemistry, v.63, p.200-208, 2013. https://doi.org/10.1016/j. plaphy.2012.11.026

Santiago, F. S.; Montenegro, A. A. de A.; Montenegro, S. M. G. L. Avaliação de parâmetros hidráulicos e manejo da irrigação por microaspersão em área de assentamento. Engenharia Agrícola, v.24, p.632- 643, 2004.
Santos, C. S. dos.; Santos, D. P. dos.; Oliveira, W. J. de.; Silva, P. F. da.; Santos, M. A. L. dos; Fontenele, A. J. P. B. Evapotranspiração de referência e coeficiente de cultivo da pimenteira no agreste alagoano. Revista Brasileira de Agricultura Irrigada, v.10, p.883892, 2016. https://doi.org/10.1590/S0100-69162004000300015

Santos, F. X. dos; Montenegro, A. A. de A.; Silva, J. R.; Souza, E. R. Determinação do consumo hídrico da cenoura utilizando lisímetros de drenagem, no agreste pernambucano. Revista Brasileira de Ciências Agrárias, v.4, p.304-310, 2009. https://doi. org/10.1590/S0100-69162008000100012

Santos, F. X. dos; Rodrigues, J. J. V.; Montenegro, A. A. de A.; Moura, R. F. de. Desempenho de lisímetro de pesagem hidráulica de baixo custo no semiárido nordestino. Engenharia Agrícola, v.28, p.115124, 2008. https://doi.org/10.7127/rbai.v10n500458

Silva, J. R. L. da; Montenegro, A. A. de A.; Santos, T. E. M. dos; Santos, E. S. dos. Desempenho de diferentes métodos de estimativa da evapotranspiração de referência para Fernando de Noronha. Irriga, v.19, p.390-404, 2014. https://doi.org/10.15809/ irriga.2014v19n3p390

Tagliaferre, C.; Silva, R. A. de J.; Rocha, F. A.; Santos, L. da C.; Silva, C. dos S. da. Estudo comparativo de diferentes metodologias para determinação da evapotranspiração de referência em Eunápolis - BA. Revista Caatinga, v.23, p.103-111, 2010.

Tanaka, A. A.; Souza, A. P. de.; Klar, A. E.; Silva, A. C. da.; Gomes, A. W. A. Evapotranspiração de referência estimada por modelos simplificados para o Estado do Mato Grosso. Pesquisa Agropecuária Brasileira, v.51, p.91-104, 2016. https://doi. org/10.1590/S0100-204X2016000200001

Willmott, C. J.; Ackleson, S. G.; Davis, R. E.; Feddema, J. J.; Klink, K. M.; Legates, D. R.; O’Donnell, J.; Rowe, C. M. Statistics for the evaluation and comparison of models. Journal of Geophysical Research, v.90, p.8995-9005, 1985. https://doi.org/10.1029/JC090iC05p08995 